\section{Influence of the Extended Use of Desensitizing Toothpastes on Dentin Bonding, Microhardness and Roughness}

\author{
Juliana Dias Aguiar ${ }^{1}$, Igor Studart Medeiros ${ }^{1}$, Mário Honorato Silva e Souza \\ Junior ${ }^{2}$, Sandro Cordeiro Loretto ${ }^{2}$
}

'Department of Biomaterials and Oral Biology, Dental School, USP - Universidade de São Paulo, São Paulo, SP, Brazil ${ }^{2}$ Department of Restorative Dentistry, Dental School, UFPA - Universidade Federal do Pará, Belém, PA, Brazil

Correspondence: lgor Studart Medeiros, Avenida Professor Lineu Prestes, 2227, 05508-000 São Paulo, SP, Brasil. Tel: +55-11-30917840. e-mail: igorsm@usp.br

\begin{abstract}
The aim of this study was to evaluate the influence of an extended use of desensitizing toothpastes (DTs) on dentin bonding, microhardness and roughness. One hundred and twenty bovine incisor teeth were randomly divided into four groups: G1, distilled water (WATER); G2, Colgate Total 12 (CT12); G3, Colgate Sensitive Pro-Relief (CSPR); and G4, Sensodyne Repair \& Protect (SRP). Dentin surfaces were etched with 17\% EDTA and 2 years of simulated tooth brushing $(20,000$ cycles) was performed on their surfaces. Knoop microhardness, surface roughness and scanning electron microscopy (SEM) were performed before and after the simulated tooth brushing. For microshear bonding test, a 2-step self-etching adhesive system (Clearfil SE Bond) was used and $0.8 \mathrm{~mm}$ diameter composite resin (Filtek Z350 XT) cylinders were built. Microshear test was performed with an orthodontic wire and with a crosshead speed of $0.5 \mathrm{~mm} / \mathrm{min}$. The data were analyzed for: 1) bond strength (one-way ANOVA), 2) microhardness intra-group (Student's test) and inter-group (one-way ANOVA/Tukey's test) comparisons, 3) roughness intra-group (Student's test/Wilcoxon's test) and inter-group (Kruskal-Wallis/Student-NewmanKeuls test) comparisons. The extended use of both dentifrices (conventional and for sensitive teeth) did not affect the bond strength and produced a significant increase in microhardness and roughness of the dentin, except for the microhardness of the SRP group. The simulated tooth brushing technique with water produced an increase in roughness, without reducing significantly the dentin microhardness.
\end{abstract}

Key Words: dentin sensitivity, toothbrushing, shear strength, hardness, surface properties.

\section{Introduction}

Dentin hypersensitivity (DH) is a condition often found in dental clinics, with a prevalence of 25-46\% among people between the ages of 18 to 70 years (1). The hydrodynamic theory is the most widely accepted explanation for the mechanisms of DH. According to it, fluids within the dentinal tubules can be disturbed by physical stimuli, such as temperature and osmosis, moving the nerve terminations, which surround the odontoblast extensions, thus triggering a painful sensation (2). Two conditions must occur for the emergence of $\mathrm{DH}$ : dentin exposure and open dentinal tubules $(3,4)$. The structure and surface of a sensitive dentin differs from those of a non-sensitive dentin, with a greater permeability observed in the sensitive dentin $(3,5)$.

There are two scientifically proposed methods for treating DH: the suppression of nerve impulses and the occlusion of exposed dentinal tubules (3-7). The latter describes the deposition of an obliterating material onto the dentin surface or within the dentinal tubules, resulting in a reduction of their respective diameters, diminishing the movement of the fluids and consequently decreasing mechanoreceptor stimulation $(7,8)$

Several active ingredients have been used to manage $\mathrm{DH}$, in both professional and home use (9). Although many products have been developed to obliterate dentinal tubules, the effects are usually temporary and DH returns when these tubule-occluding agents are removed, due to the erosion caused by daily dietetic challenges $(7,8)$.

An alternative new desensitizing toothpaste was introduced in the market with the trade name of Colgate Sensitive Pro-Relief (Colgate-Palmolive, São Paulo, SP, Brazil), which is basically composed of arginine and calcium carbonate (Pro-Argin ${ }^{\circledR}$ ), and acts by remineralizing exposed hypersensitive dentin. Arginine is an aminoacid found naturally in saliva which is able to physically block and seal open dentinal tubules if combined with calcium carbonate and deposited on an exposed dentin surface $(6,10)$.

Another recent remineralizing alternative for $\mathrm{DH}$ control is a calcium sodium phosphosilicate-based toothpaste $\left(\right.$ NovaMin $\left.{ }^{\circledR}\right)$, an amorphous inorganic compound classified as a bioactive glass. This product is known commercially as Sensodyne Repair \& Protect (GlaxoSmithKline, Rio de Janeiro, RJ, Brazil) and it undergoes a series of chemical reactions when in contact with an aqueous solution. Its interaction with this solution results in the formation of a carbonated hydroxyapatite layer on the dentinal surface, i.e. forming an insoluble mineralized layer on its surface. 
$(1,3,11,12)$.

Although many clinical and laboratory studies have reported the action mechanism of substances present in these desensitizing and remineralizing toothpastes, besides their efficacy in relieving painful sensations $(7,8,10,12,13)$, little is known about the influence of an extended use of these toothpastes on dentin tissue.

Therefore, due to a continuous (daily) therapeutic recommendation for using these products, it is relevant to assess the effects of these toothpastes on properties such as dentin microhardness and roughness, as well as whether these occlusive therapies may interfere with dentin bond strength when the need for a subsequent restorative treatment arises.

The hypotheses tested were that extended use of desensitizing toothpastes significantly influences dentin bond strength, microhardness and roughness.

\section{Material and Methods}

The study was approved by the Research Ethics Committee with Test Animals (CEPAE-181-Protocol 13). One hundred and twenty sound bovine teeth were collected, washed in running water and stored in a $0.1 \%$ thymol disinfectant solution for 1 week. After disinfection, the teeth were analyzed with a stereo magnifier (40x) to detect cracks and/or fractures, followed by storage in distilled water $\left(4^{\circ} \mathrm{C}\right)$, replaced weekly. The materials used in the study are listed in Table 1.

\section{Preparation of the Samples}

The vestibular surface of each tooth was flattened in a polishing machine (Aropol-and-Arotec, Cotia, SP, Brazil) using 180-grit sandpaper (3M, Sumaré, SP, Brazil) until superficial dentin exposure occurred, followed by marking the middle third of the crown, corresponding to delineations where the specimens were to be cut.

Dentin surfaces were sectioned with a doublesided diamond disc (KG Sorensen, Cotia, SP, Brazil) to obtain dentin blocks that were placed into a PVC matrix with the following dimensions: $10 \times 5 \times 2 \mathrm{~mm}$ (for bond strength), $6 \times 4 \times 2 \mathrm{~mm}$ (for roughness), and $4 \times 4 \times 2 \mathrm{~mm}$ (for microhardness and SEM). For the microshear test, the specimens were prepared with 400- and 600-grit silicon carbide sandpaper. The remaining specimens, intended for other tests, were additionally prepared with 1200- and 2000-grit sandpaper.

Next, 17 \% EDTA solution (Fórmula \& Ação, São Paulo, $\mathrm{SP}$, Brazil) was applied to the dentin surfaces for $1 \mathrm{~min}$, followed by an ultrasonic bath (1 $\mathrm{min}$ ) and washing with $20 \mathrm{~mL}$ distilled water to clean the surfaces (removal of the smear layer), simulating hypersensitive dentin. The specimens were randomly divided into 4 experimental groups according to the desensitizing toothpaste (active ingredient) to be used (Table 2).

\section{Simulated Tooth Brushing}

For the tooth brushing simulation, a brushing machine

Table 1. Description of materials used, including brand name, manufacturers, classification, composition

\begin{tabular}{|c|c|c|c|}
\hline Material & Manufacturer & Classification & Composition \\
\hline $\begin{array}{l}\text { Colgate Total } 12 \\
(\mathrm{RDA}=70)\end{array}$ & $\begin{array}{l}\text { Colgate-Palmolive, } \\
\text { São Bernardo do } \\
\text { Campo, SP, Brazil }\end{array}$ & Toothpaste & $\begin{array}{l}\text { Sodium fluoride (1450 ppmF), triclosan, hydrated silica, water, glycerin, sorbitol, } \\
\text { PVM/MA copolymer, sodium lauryl sulfate, flavor, cellulose gum, sodium } \\
\text { hydroxide, propylene glycol, carrageenan, sodium saccharin, titanium dioxide. }\end{array}$ \\
\hline $\begin{array}{l}\text { Colgate Sensitive } \\
\text { Pro-Relief } \\
(\mathrm{RDA}=125)\end{array}$ & $\begin{array}{l}\text { Colgate-Palmolive, } \\
\text { São Bernardo do } \\
\text { Campo, SP, Brazil }\end{array}$ & $\begin{array}{l}\text { Desensitizing } \\
\text { toothpaste }\end{array}$ & $\begin{array}{l}\text { Arginine 8\%, Calcium carbonate, aqua, sorbitol, bicarbonate, } \\
\text { sodium lauryl sulfate, sodium monofluorophosphate (1450 ppmF), } \\
\text { aroma, sodium silicate, cellulose gum, sodium bicarbonate, titanium } \\
\text { dioxide, potassium acesulfame, xanthan gum, sucralose. }\end{array}$ \\
\hline $\begin{array}{l}\text { Sensodyne } \\
\text { Repair \& Protect } \\
(\mathrm{RDA}=104)\end{array}$ & $\begin{array}{l}\text { GlaxoSmithKline, } \\
\text { Rio de Janeiro, } \\
\text { RJ, Brazil }\end{array}$ & $\begin{array}{l}\text { Desensitizing } \\
\text { toothpaste }\end{array}$ & $\begin{array}{l}\text { Glycerin, PEG-8, silica, calcium sodium phosphosilicate 5\% } \\
\text { (NOVAMIN), cocamidopropyl betaine, sodium methyl cocoyl } \\
\text { taurate, sodium monofluorophosphate ( } 1450 \mathrm{ppmF} \text { ), aroma, } \\
\text { titanium dioxide, carbomer, sodium saccharin, limonene. }\end{array}$ \\
\hline Clearfil SE Bond & $\begin{array}{l}\text { Kuraray, Sakazu, } \\
\text { Kurashiki, } \\
\text { Okayama, Japan }\end{array}$ & $\begin{array}{l}\text { 2-step } \\
\text { self-etching } \\
\text { adhesive } \\
\text { system }\end{array}$ & $\begin{array}{l}\text { Primer: Water, MDP, HEMA, hydrophilic dimethacrylates, camphorquinone. } \\
\text { Bond: MDP, Bis-GMA, HEMA, camphorquinone hydrophobic } \\
\text { dimethacrylate, N/N-diethanol p-toluidine bond, colloidal silica. }\end{array}$ \\
\hline $\begin{array}{l}\text { Filtek Z350 } \\
\text { XT (A2D) }\end{array}$ & $\begin{array}{c}\text { 3M Espe, Sumaré, } \\
\text { SP, Brazil }\end{array}$ & $\begin{array}{c}\text { Nanofiller } \\
\text { composite resin }\end{array}$ & $\begin{array}{c}\text { Organic matrix: Bis-GMA, UDMA, Bis-EMA 6, and small quantities of TEGDMA. } \\
\text { Inorganic filler: Non-agglomerated nanoparticles of silica } \\
\text { 20nm in size and nanoagglomerates formed of zirconium/ } \\
\text { silica particles ranging from } 0.6 \text { to } 1.4 \mathrm{~mm} \text { in size. }\end{array}$ \\
\hline Artificial saliva & $\begin{array}{l}\text { “A Fórmula” - } \\
\text { Compounding } \\
\text { Pharmacy, Belém, } \\
\text { PA, Brazil }\end{array}$ & - & $\begin{array}{l}2190 \mathrm{mg} \text { sodium bicarbonate, } 125 \mathrm{mg} \text { magnesium chloride, } 820 \mathrm{mg} \\
\text { potassium chloride, } 10 \mathrm{mg} \text { nipagin, } 24 \mathrm{mg} \text { sorbitol, } 1270 \mathrm{mg} \text { potassium } \\
\text { phosphate, } 441 \mathrm{mg} \text { calcium chloride, } 4.5 \mathrm{mg} \text { sodium fluoride, } 100 \mathrm{mg} \\
\text { nipasol, } 8 \mathrm{mg} \text { carboxymethylcellulose, and } 3000 \mathrm{~mL} \text { distilled water (pH=7) }\end{array}$ \\
\hline
\end{tabular}


from the Department of Biomaterials and Oral Biology, School of Dentistry, University of São Paulo (São Paulo, $\mathrm{SP}$, Brazil) was used. Soft toothbrushes (Oral-B Indicator Plus 35, Manaus, AM, Brazil) were attached to the ends of the machine arms with bolts. The samples were set in brushing capsules in a way that they protruded $1 \mathrm{~mm}$ beyond the base, allowing for efficient and uniform action of the brush bristles.

Each dentinal surface underwent 20,000 cycles, simulating approximately 2 years of brushing (14). The brushing speed was 2 cycles/s, with a load of $2 \mathrm{~N}$ on the brushes. While brushing, a dilution of toothpaste and water was used ( $1: 2$ ratio by weight); it was prepared immediately before use to preserve its characteristics and $40 \mathrm{~g}$ of this dilution was placed in the machine containers.

After 10,000 cycles, the brushes were replaced and the container that housed the specimens was inverted $\left(180^{\circ}\right)$ to change its position. At the end of brushing, the specimens were removed and washed for 30 s running water and then stored in artificial saliva $\left(37^{\circ} \mathrm{C} / 24 \mathrm{~h}\right)$.

\section{Preparation of the Specimens and the Mechanical} Microshear Test

Sixteen specimens were used, four in each experimental group. The bonding area was marked with 1-mm diameter perforated double-sided adhesive tape (Tectape, Manaus, AM, Brazil). Next, the Clearfil SE Bond adhesive system (Kuraray, Sakazu, Kurashiki, Okayama, Japan) was applied according to the manufacturer's recommendations (active application of primer for $20 \mathrm{~s}$, light airflow for $3 \mathrm{~s}$, application of the bonding adhesive and light airflow for 3 s), then photo-activated (Bluephase; Ivoclar Vivadent, Schaan, Liechtenstein) $\left(1200 \mathrm{~mW} / \mathrm{cm}^{2}\right)$ for $20 \mathrm{~s}$.

Subsequently, the first layer of tape was removed and a Tygon ${ }^{\circledR}$ tube $(0.8 \mathrm{~mm}$ diameter $\times 0.5 \mathrm{~mm})$ was positioned to align with the marked area. The tube was filled with FiltekZ350 XT composite resin (3M ESPE, Sumaré, SP, Brazil), photo-activated for $40 \mathrm{~s}$. After making 3 composite resin cylinders for each specimen, the specimens were stored

Table 2. Division of groups, according to toothpaste and desensitizing agent (active ingredient)

\begin{tabular}{|c|c|c|}
\hline Group & Toothpaste & $\begin{array}{l}\text { Desensitizing agent } \\
\text { (active ingredient) }\end{array}$ \\
\hline G1 & $\begin{array}{l}\text { Distilled water (negative } \\
\text { control) - WATER }\end{array}$ & - \\
\hline G2 & Colgate Total 12 - CT12 & - \\
\hline G3 & $\begin{array}{l}\text { Colgate Sensitive } \\
\text { Pro-Relief - CSPR }\end{array}$ & $\begin{array}{l}\text { Pro-Argin }{ }^{\circledR} \text { ( } 8 \% \text { arginine } \\
\text { and calcium carbonate) }\end{array}$ \\
\hline G4 & $\begin{array}{l}\text { Sensodyne Repair } \\
\text { \& Protect - SRP }\end{array}$ & $\begin{array}{l}\text { Novamin }^{\circledR} \text { (5\% calcium and } \\
\text { sodium phosphosilicate) }\end{array}$ \\
\hline
\end{tabular}

in distilled water $\left(37^{\circ} \mathrm{C} / 24 \mathrm{~h}\right)$; later the Tygon tubes were removed. The specimens were fixed to a universal testing machine (KRATOS KE, Cotia, SP, Brazil) and the microshear test was performed with a 0.008 " diameter orthodontic wire (Morelli, Sorocaba, SP, Brasil) at a crosshead speed of $0.5 \mathrm{~mm} / \mathrm{min}$.

\section{Analysis of Fracture Patterns}

After the microshear test, the fractured surfaces were assessed with a stereomicroscope at $\times 0.8$ magnification (SZ2-ILST, Olympus SZ61, Tokyo, Japan) and the fracture patterns classified as: $A$, adhesive; $C D$, cohesive in dentin; $C R$, cohesive in composite resin; and $M$, mixed.

\section{Microhardness}

Forty-eight teeth were used $(n=12)$. The dentinal surfaces of the specimens were divided into two halves for delimitation, where the initial and final readings were taken. The Knoop microhardness (HMV-2; Shimadzu, Kyoto, Japan) test was performed with a load of $50 \mathrm{~g}$ for $20 \mathrm{~s}$ and the reading was made at $40 \times$ magnification. Five indentations were made, and the initial microhardness value of each specimen was obtained by the arithmetic mean. After the brushing process, the specimens were washed under running water and stored in artificial saliva $\left(37^{\circ} \mathrm{C} / 24 \mathrm{~h}\right)$ until the final microhardness readings were obtained, as previously described.

\section{Roughness}

Forty-eight teeth were used ( $n=12$ per group). Roughness was measured in $\mathrm{Ra}(\mu \mathrm{m})$ by contact profilometry (Desktak 150, Veeco, AZ, USA). Regarding the scanning parameters, the standard mode was used with a $2000 \mu \mathrm{m}$ length and duration of $12 \mathrm{~s}$ at a resolution of $0.556 \mu \mathrm{m} / \mathrm{sample}$. An applied force of $3.00 \mathrm{mg}$ was used, a stylus radius of $12.5 \mu \mathrm{m}$ and the "Hills \& Valleys" profile were adopted. Five random readings were performed for each specimen, using the arithmetic mean to obtain the initial roughness value. The device was calibrated every 5 readings. After brushing, the specimens were washed under running water and stored in artificial saliva (37 ${ }^{\circ} \mathrm{C} / 24 \mathrm{~h}$ ) until the final roughness readings were obtained, as previously described.

\section{Field-emission Gun Scanning Electron Microscopy (FEG-SEM)}

Eight teeth were used for qualitative analysis using FEG-SEM (Inspect F-50; FEl, Eindhoven, The Netherlands). Two blocks were obtained from each dentin surface $(4 \times 4 \times 2$ $\mathrm{mm})$. One of the blocks was used for dentinal surface evaluation before brushing (control) and the other for comparison after brushing $(n=2)(5000 x)$. 


\section{Statistical Analysis}

The normality of the data was checked by the ShapiroWilk test. The analysis of bond strength was made by one-way ANOVA. Intra-group (Student's t test) and intergroup (one-way ANOVA and Tukey's test) comparisons of microhardness were also performed. Additionally, roughness was compared within (Student's t test and Wilcoxon's test) and between the groups (Kruskal-Wallis test and StudentNewman-Keuls test). The level of statistical significance adopted was 5\%.

\section{Results}

\section{Bond Strength}

The averages (standard deviations) of the bond strength values (MPa), as well as the percentages of the fracture patterns, are in Table 3.

One-way ANOVA showed that there was no statistically significant difference between the groups $(p=0.1244)$. The highest incidence of mixed fracture pattern occurred in the control group (WATER), while adhesive fractures were

Table 3. Bond strength means (MPa) and standard deviation, and percentage of fracture patterns

\begin{tabular}{lccc}
\hline \multirow{2}{*}{ Groups (n=12) } & Mean (SD) & \multicolumn{2}{c}{ Fracture patterns } \\
\cline { 3 - 4 } & & Adhesive & Mixed \\
\hline Water & $17.67(5.77) \mathrm{A}$ & $8.33 \%$ & $91.67 \%$ \\
Colgate Total 12 & $12.24(6.74) \mathrm{A}$ & $58.33 \%$ & $41.67 \%$ \\
$\begin{array}{l}\text { Colgate Sensitive } \\
\text { Pro-Relief }\end{array}$ & $15.95(4.81) \mathrm{A}$ & $41.67 \%$ & $58.33 \%$ \\
$\begin{array}{l}\text { Sensodyne Repair } \\
\& \text { Protect }\end{array}$ & $13.30(6.63) \mathrm{A}$ & $66.67 \%$ & $33.33 \%$ \\
\hline
\end{tabular}

Same letter within the same column indicates no statistically significant difference.

Table 4. Means and standard-deviations (SD) of microhardness (KHN) and roughness $(\mu \mathrm{m})$, before (initial) and after (final) toothbrushing, according to t de Student's test

\begin{tabular}{|c|c|c|c|c|c|c|}
\hline \multirow{3}{*}{ Groups $(n=12)$} & \multirow{2}{*}{\multicolumn{2}{|c|}{$\begin{array}{c}\text { Microhardness } \\
\text { Mean (SD) }\end{array}$}} & \multirow{3}{*}{$\mathrm{p}$ value } & \multirow{2}{*}{\multicolumn{2}{|c|}{$\begin{array}{l}\text { Roughness } \\
\text { Mean (SD) }\end{array}$}} & \multirow{3}{*}{$\mathrm{p}$ value } \\
\hline & & & & & & \\
\hline & Initial & Final & & Initial & Final & \\
\hline Distilled water & $\begin{array}{l}62.23 \\
(8.98)\end{array}$ & $\begin{array}{l}55.61 \\
(8.50)\end{array}$ & 0.1144 & $\begin{array}{l}0.147 \\
(0.01)\end{array}$ & $\begin{array}{l}0.180 \\
(0.04)\end{array}$ & ${ }^{* *} 0.0047^{*}$ \\
\hline Colgate Total 12 & $\begin{array}{c}63.63 \\
(13.60)\end{array}$ & $\begin{array}{l}78.55 \\
(9.68)\end{array}$ & $0.0049^{*}$ & $\begin{array}{l}0.144 \\
(0.03)\end{array}$ & $\begin{array}{l}1.737 \\
(0.96)\end{array}$ & $0.0001^{*}$ \\
\hline $\begin{array}{l}\text { Colgate } \\
\text { Sensitive } \\
\text { Pro-Relief }\end{array}$ & $\begin{array}{l}59.22 \\
(9.22)\end{array}$ & $\begin{array}{l}65.50 \\
(8.79)\end{array}$ & $0.0198^{*}$ & $\begin{array}{l}0.139 \\
(0.02)\end{array}$ & $\begin{array}{l}0.236 \\
(0.06)\end{array}$ & $0.0001^{*}$ \\
\hline $\begin{array}{l}\text { Sensodyne } \\
\text { Repair \& Protect }\end{array}$ & $\begin{array}{c}67.69 \\
(10.15)\end{array}$ & $\begin{array}{c}68.57 \\
(11.18)\end{array}$ & 0.7667 & $\begin{array}{l}0.158 \\
(0.03)\end{array}$ & $\begin{array}{l}0.356 \\
(0.14)\end{array}$ & $0.0001^{*}$ \\
\hline
\end{tabular}

*Significative at 5\%. ** Wilcoxon's test. more frequent in the SRP group. There were no cohesive fracture patterns in dentin (CD) or in composite resin (CR) in the groups.

\section{Microhardness and Roughness}

Table 4 shows the averages (standard deviations), intra-group microhardness and roughness comparisons (before and after brushing) according to Student's $t$ and Wilcoxon's tests.

For microhardness, there were statistically significant increases in the Colgate Total 12 (CT12) $(p=0.0049)$ and Colgate Sensitive Pro-Relief (CSPR) ( $p=0.0198)$ groups. All groups exhibited significant increases in roughness $(p<0.05)$.

According to one-way ANOVA, the difference in microhardness (final - initial) between the groups was highly significant $(p<0.0001)$, and Tukey's test demonstrated this difference between the WATER and CT12 groups $(p<0.01)$, as well as between the CT12 and Sensodyne Repair \& Protect $(S R P)(p<0.05)$ groups. The Kruskal-Wallis test showed that the difference in roughness (final - initial) was also highly significant between the groups $(p<0.0001)$, and the Student-Newman-Keuls test identified differences between the following groups: WATER and CT12 $(p<0.0001)$; WATER and SRP $(p<0.0049) ;$ CT12 and CSPR $(p<0.0001)$; and CT12 and SRP $(p<0.0034)$ (Table 5).

\section{Scanning Electron Microscopy}

Figure 1 shows the dentinal surfaces before and after brushing. In Figure $1 \mathrm{~A}$, the absence of a smear layer and open dentinal tubules may be observed after treatment with 17\% EDTA for 1 min. Figure 1B (WATER) highlights the unique action of the toothbrush on the substrate, where some debris are seen on the inter-tubular and intra-tubular dentin, caused by the dentin content deposited on the surface after abrasion. In contrast, Figures $1 \mathrm{E}$ (SRP) and 1D (CSPR) display total and partial occlusion of the dentinal tubules, respectively. In Figure 1C (CT12) intra-tubular and dentinal surface deposits are possibly represented by silica. In Figure 1D (CSPR) and Figure 1E (SRP), the formed mineral deposits may be a result of the reactions of arginine/calcium carbonate and sodium phosphosilicate with calcium and the dentinal surface, respectively. These deposits may also be from the abrasives in the toothpastes, like calcium carbonate and sodium silicate (CSPR) and silica (SRP).

\section{Discussion}

Considering the obtained results, the tested hypotheses may be partially accepted. 
Besides the fact that the extended use of arginine/calcium carbonate (CSPR) and calcium and sodium phosphosilicatebased (SRP) desensitizing toothpastes did not interfere significantly with bonding strength to dentin, it did influence the microhardness and roughness of the substrate.

In the microshear test, considering desensitizing toothpastes, the study results agree with other studies available in the literature (15-18), demonstrating that the use of these toothpastes did not affect the bonding to dentin compared to the control group and included a discrete increase in bond strength values (16).

This result can be justified by the fact that arginine/ calcium carbonate and calcium and sodium phosphosilicate in water, may reduce surface tension and increase dentin wettability, its surface energy and reduce the contact angle of the bonding system with the substrate, improving the adhesion process. Besides, the richly mineralized layer formed by deposited calcium phosphate on the surface of exposed dentin can fill weak areas in the future hybrid layer (18).

It is also possible that the mineral deposits formed by the desensitizing toothpastes above are unstable (18) or not tenacious enough to affect the formation of the $\vec{\sigma}$ hybrid layer (17) and therefore do not interfere with bond strength. Active application of the adhesive system may also have contributed. Thus, the remnants of the smear layer, and even the formed mineral deposits, were completely dispersed or dissolved, favoring the formation of a thick hybrid layer and integrated collagen fibers (19).

In fact, the photomicrographs (FEG-SEM) demonstrated that the application of CSPR (Fig. 1D) produced only a partial occlusion of the exposed dentinal tubules, whereas SRP (Fig. 1E) occluded most tubules, allowing particle deposition in the inter-tubular dentin and also formation

Table 5. Means of differences between final and initial microhardness (KHNf - KHNi), and final and initial roughness (Raf - Rai), as well as, maximum and minimum values of differences

\begin{tabular}{lcc}
\hline \multirow{2}{*}{ Groups } & \multicolumn{1}{c}{ Microhardness* $^{*}$ Roughness** $^{* *}$} \\
\cline { 2 - 3 } & KHNf-KHNi (min/max) & Raf - Rai (min/max) \\
\hline $\begin{array}{l}\text { Distilled water } \\
\text { Colgate }\end{array}$ & $-6.61(-33.70 / 11.28) \mathrm{A}$ & $0.04(0.00 / 0.15) \mathrm{A}$ \\
$\begin{array}{l}\text { Total 12 } \\
\text { Colgate }\end{array}$ & $14.93(-6.34 / 45.30) \mathrm{B}$ & $1.59(0.60 / 3.36) \mathrm{B}$ \\
$\begin{array}{l}\text { Sensitive } \\
\text { Pro-Relief }\end{array}$ & $6.28(-11.92 / 16.72) \mathrm{ABC}$ & $0.10(0.03 / 0.23) \mathrm{AC}$ \\
$\begin{array}{l}\text { Sensodyne } \\
\text { Repair \& }\end{array}$ & $0.89(-14.50 / 15.82) \mathrm{AC}$ & $0.20(0.02 / 0.41) \mathrm{C}$ \\
Protect & & \\
\hline
\end{tabular}

According to 1-way ANOVA and Tukey's test. **According to KruskalWallis' test and Student-Newman-Keuls' test. Same capital letters indicate statistically similar groups at the same column. of a protective layer on the dentinal surface.

Considering the microhardness results after brushing, the CT12 and CSPR groups presented significant increases, which were not observed with SRP. It is known that isolated dental brushing (without toothpaste) for a long time and with normal frequency (twice daily), presents minimal wear to the dentin substrate $(20,21)$. This fact can explain the observations in the WATER (control) group, which presented no significant reduction in microhardness values. On the other hand, when brushing is accomplished with fluoridecontaining toothpastes, an increase in microhardness values is expected, induced by greater mineralization of the dental tissues, or an increased resistance of these tissues to demineralization (22).

Although the SRP group showed great dentin microhardness values, this increase did not have statistical relevance, which does not agree with the findings of Parkinson and Willson (13). According to these authors, an increase in microhardness after the brushing process, with fluoride toothpaste containing calcium and sodium phosphosilicate (CSPS), was consistent with mineralization of the dentinal surface and formation of mineral deposits, which presented greater hardness than the dentin because of the chemical nature of CSPS. Moreover, the increase in the substrate hardness may be attributed to the presence of un-reacted CSPS particles attached (bound) to the dentin surface (11), toothpaste excipients and the formation of several species of calcium phosphate on the dentinal surface.

Studies by Burwell et al. (23) and Wang et al. (24) also showed recoveries in microhardness values and increases in the mineral content of the dentin tissue, respectively, after exposure to calcium sodium phosphosilicate (SRP). However, the differences observed regarding the results of the present study may be associated with the studies' distinct objectives and methodological design. This research evaluated the effects of extended use of desensitizing toothpastes on dentin tissue by performing 20,000 continuous cycles of simulated tooth brushing, which corresponds to approximately 2 years of tooth brushing (14). Additionally, the storage duration of the specimens in artificial saliva after brushing ( $24 \mathrm{~h})$ may have been insufficient to induce an increase in dentin mineralization in the SRP group considering the obtained microhardness results, which was not observed in the CSPR group.

Thus, despite the possible positive effects of fluoride on microhardness values in groups subjected to brushing with different toothpastes, the remineralizing contributions of arginine/calcium carbonate (CSPR) and calcium sodium phosphosilicate (SRP) in the obtained results cannot be disregarded, as already reported in the literature $(13,23,24)$.

Despite of the three toothpastes presenting the 
same fluoride concentration (1450 ppm), there was an increase of microhardness for CT12 and CSPR groups. This may be justified by different compositions among the manufacturers' materials. Nevertheless, the three toothpastes have different expiration dates (Table 1), and the greatest difference of expiry (2 years) is between the CT12 and CSPR, which could represent a limiting factor of the study, so the microhardness results should be interpreted with caution.

Regarding dentin roughness, a significant increase was observed in all groups after brushing, with the greatest difference demonstrated in the CT12 (control) group (Table 4). Furthermore, comparing the groups, the CSPR desensitizing toothpaste group was statistically similar to the WATER (control) and SRP groups, with the CT12 group exhibiting significantly greater roughness than the other groups (Table 5). Possibly the differences in the compositions
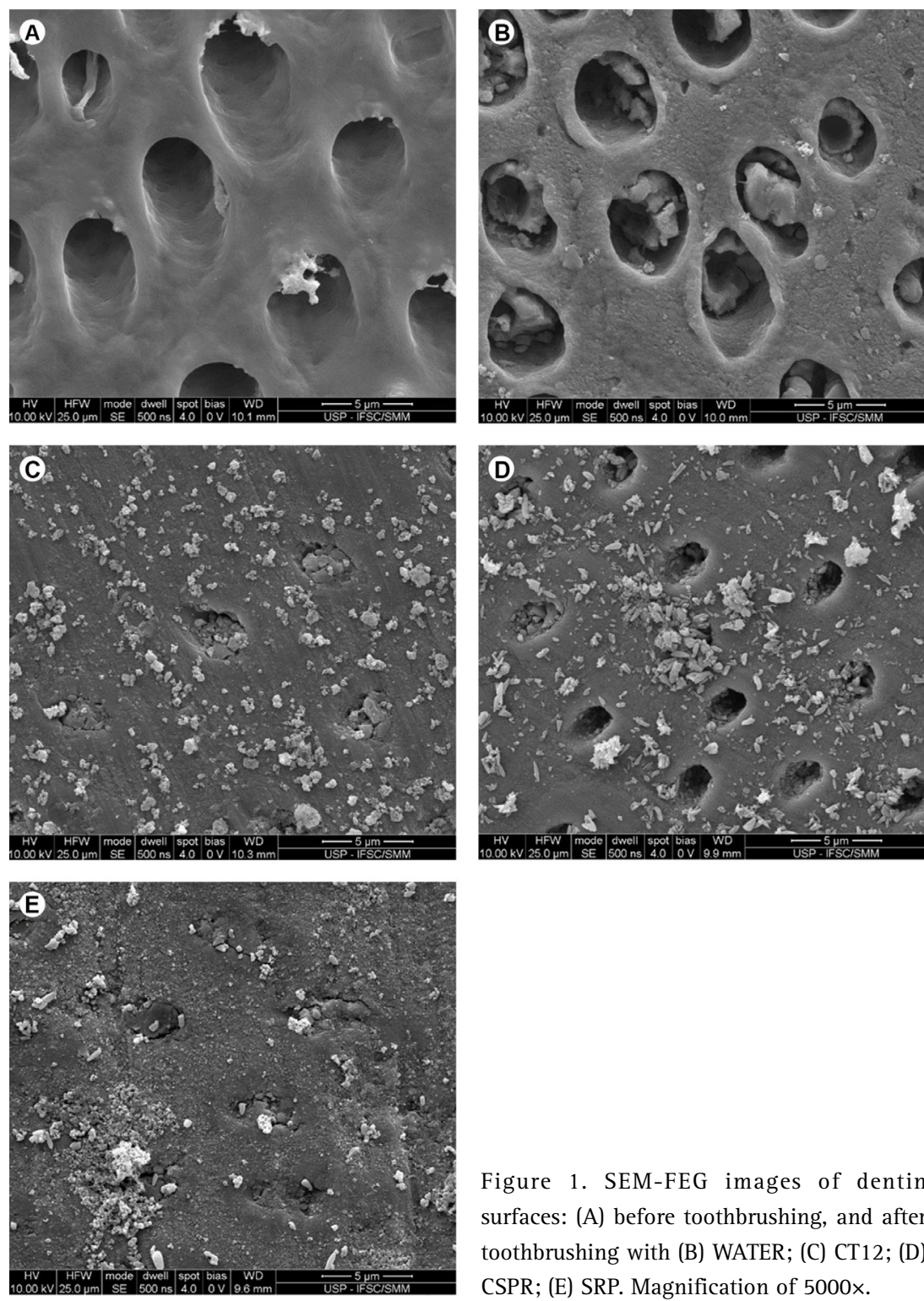

Figure 1. SEM-FEG images of dentin surfaces: (A) before toothbrushing, and after toothbrushing with (B) WATER; (C) CT12; (D) CSPR; (E) SRP. Magnification of 5000x. of the tested toothpastes justify such results.

A wide variety of abrasive systems are present in toothpaste, including hydrated silica, alumina, dicalcium phosphate dihydrate, insoluble metaphosphate and calcium carbonate, among other polishing agents (21). The most commonly used are derivatives of silica (25), incorporated to ensure the removal of bacterial plaque and reduce the build-up of other superficial deposits on the tooth structure. The abrasiveness of a toothpaste can be influenced by the difference in hardness between the abrasive and the dentin, the composition and microstructure of the abrasive, its concentration, size and shape (26). The larger CT12 roughness values may be related to the hydrated silica that has increased hardness compared to calcium carbonate in the CSPR.

In the present study, although used as a control, CT12 presented a significant increase in roughness compared to the tested desensitizing toothpastes (CSPR and SRP), even though it presented a low Relative Dentin Abrasivity (RDA) with a value of 70 . The characteristics of the abrasive particles, along with the chemical influences of other ingredients in the toothpastes, may explain these findings (25-27).

The detergents in the formulation of dentifrices can modify the abrasiveness characteristics. Moore and Addy (28) observed that brushing exclusively with detergents potentially caused dentin loss, clarifying that the loss was determined from the rheological properties of the final mixture (in the case of toothpastes) combined with the chemical action of the detergent. Moreover, the authors further stated that the abrasive properties of the types of silica used in toothpastes varied, regardless of similarities in particle size.

In addition, the in vitro abrasive behavior of toothpastes may be influenced by the number of the brushing cycles, without a linear relationship between the number of cycles and the observed tissue abrasion $(25,28)$. Therefore, when direct comparisons between the results of different studies are portrayed, this methodological 
aspect should be considered.

The most common and accepted method to evaluate the abrasiveness of toothpastes today are RDA values, which are considered a quantitative method based on measuring the amount of abraded or removed material. However, the RDA does not measure the roughness (texture) of the abraded surface, a qualitative measurement relevant to characterizing the abrasiveness of toothpastes. Besides, it is demonstrated in the literature that there is a weak correlation between the RDA, roughness values and loss of tissue volume caused by different toothpastes when describing the abrasiveness of these products, measured by profilometry techniques $(25,27)$.

Thus, this information is of extreme relevance in clinical practice, due to the fact that nowadays the abrasiveness of toothpastes is often based on RDA values. For example, toothpastes with low RDA values are recommended for patients in specific situations, such as those with $\mathrm{DH}$, gum recession and so forth (25).

In the conducted study, CSPR desensitizing toothpaste resulted in a roughness statistically similar to the WATER control group, despite its high RDA value of 125 . Considering that the literature demonstrates that brushing s without toothpaste for long periods, twice a day (normal $\Xi$ use), presents minimal wear to the dentinal tissue and is restricted to the formation of the smear layer $(20,21)$, it is reasonable to expect that CSPR does not produce significant effects on the roughness of exposed dentin.

On the other hand, although SRP toothpaste $(R D A=104)$ presented a roughness statistically compatible with CSPR, it differed significantly from the WATER control group. Therefore, this toothpaste may have relevant effects on the roughness of dentinal tissue.

Thus, arginine/calcium carbonate (CSPR) and calcium and sodium phosphosilicate-based (SRP) desensitizing toothpastes, which are clinically recommended for continuous use, can interfere with relevant long-term properties of the dentin. Hence, other in situ and in vivo studies should be conducted to improve the understanding of the effects of these products on dental hard tissues.

In conclusion, the extended use of both types of dentifrices (conventional and for sensitive teeth) did not interfere in bond strength and produced a significant increase in hardness and roughness of the dentin, except for the hardness of the SRP group. Brushing with water produced an increase in roughness, without reducing significantly the dentin microhardness.

\section{Resumo}

0 objetivo deste estudo foi avaliar a influência do uso prolongado de dentifrícios dessensibilizantes (DTs) na adesão, microdureza e rugosidade da dentina. Cento e vinte dentes incisivos bovinos foram divididos aleatoriamente em quatro grupos: $\mathrm{G} 1$, água destilada (WATER); $\mathrm{G} 2$, Colgate Total 12 (CT12); G3, Colgate Sensitive Pro-alivio (CSPR); e G4, Sensodyne Repair \& Protect (SRP). As superficies dentinárias foram condicionadas com EDTA a 17\% e foram realizados 2 anos de escovação dental simulada (20.000 ciclos) em suas superficies. A microdureza Knoop, rugosidade de superficie e microscopia eletrônica de varredura (MEV) foram realizadas antes e após escovação dental simulada. Para o teste de adesão por microcisalhamento, foi aplicado um sistema adesivo auto condicionante de 2 passos (Clearfil SE Bond) e foram construidos cilindros de resina composta (Filtek Z350 XT) de 0,8 mm de diâmetro. 0 teste de microcisalhamento foi realizado com um fio ortodôntico e com velocidade de $0,5 \mathrm{~mm} / \mathrm{min}$. Os dados foram analisados para: 1) resistência de união (ANOVA 1 fator), 2) comparações de microdureza intra grupo (teste t de Student) e inter grupo (ANOVA 1 fator / teste de Tukey), 3) comparações de rugosidade intra grupo (teste t de Student / teste de Wilcoxon) e inter grupo (Kruskal Wallis/ teste de Student-Newman-Keuls). 0 uso prolongado de ambos dentifrícios (convencional e para dentes sensiveis) não interferiu na resistência de união e produziu um aumento significativo na microdureza e rugosidade da dentina, exceto para a microdureza do grupo SRP. A técnica de escovação dental simulada com água promoveu aumento na rugosidade, sem reduzir significativamente a microdureza da dentina.

\section{References}

1. Zhu M, Li J, Chen B, Mei L, Yao L, Tian J, et al.. The effect of calcium sodium phosphosilicate on dentin hypersensitivity: A systematic review and meta-analysis. PLoS One 2015;10:1-15.

2. Brannstrom $M$, Linden $L A$, Astrom $A$. The hydrodynamics of the dental tubule and of pulp fluid. A discussion of its significance in relation to dentinal sensitivity. Caries Res 1967;1:310-317.

3. Sufi F, Hall C, Mason S, Shaw D, Kennedy L, Gallob JT. Efficacy of an experimental toothpaste containing 5\% calcium sodium phosphosilicate in the relief of dentin hypersensitivity: An 8-week randomized study (Study 1). Am J Dent 2016;29:93-100.

4. Sufi F, Hall C, Mason S, Shaw D, Milleman J, Milleman K. Efficacy of an experimental toothpaste containing $5 \%$ calcium sodium phosphosilicate in the relief of dentin hypersensitivity: An 8-week randomized study (Study 2). Am J Dent 2016;29:101-109.

5. Chen CL, Parolia A, Pau A, Celerino de Moraes Porto IC. Comparative evaluation of the effectiveness of desensitizing agents in dentine tubule occlusion using scanning electron microscopy. Aust Dent $J$ 2015;60:65-72.

6. Hu D, Stewart B, Mello S, Arvanitidou L, Panagakos F, De Vizio W, et al.. Efficacy of a mouthwash containing 0.8\% arginine, PVM/MA copolymer, pyrophosphates, and $0.05 \%$ sodium fluoride compared to a negative control mouthwash on dentin hypersensitivity reduction. $A$ randomized clinical trial. J Dent 2013;41:S26-S33.

7. West N, Newcombe RG, Hughes N, Mason S, Maggio B, Sufi F, et al.. A 3-day randomised clinical study investigating the efficacy of two toothpastes, designed to occlude dentine tubules, for the treatment of dentine hypersensitivity. J Dent 2013;41:187-194.

8. Wang Q, Kang Y, Barnes V, Devizio W, Kashi A, Ren YF. Dentin tubule occlusion and erosion protection effects of dentifrice containing bioadhesive PVM/MA copolymers. Clin Oral Investig 2013;17:775-783.

9. West NX, Seong J, Davies M. Management of dentine hypersensitivity: efficacy of professionally and self-administered agents. J Clin Periodontol 2015;42 Suppl 16:S256-302.

10. Sharif MO, Iram S, Brunton PA. Effectiveness of arginine-containing toothpastes in treating dentine hypersensitivity: A systematic review. J Dent 2013;41:483-492.

11. Greenspan DC. NovaMin and tooth sensitivity - an overview. J Clin Dent 2010;21:61-65.

12. Earl JS, Leary RK, Muller KH, Langford RM, Greenspan DC. Physical and chemical characterization of dentin surface following treatment with NovaMin technology. J Clin Dent 2011;22:62-67.

13. Parkinson $\mathrm{CR}$, Willson RJ. A comparative in vitro study investigating the occlusion and mineralization properties of commercial toothpastes in 
a four-day dentin disc model. J Clin Dent 2011:22:74-81.

14. Goldstein GR, Lerner T. The effect of toothbrushing on a hybrid composite resin. J Prosthet Dent 1991;66:498-500.

15. Aguiar JD, de Amorim ACS, Medeiros IS, Souza Júnior MHS, Loretto SC. Influence of prolonged use of desensitizing dentifrices on dentin bond strength of self-etching adhesive system. Int J Odontostomatol 2016;10:135-142.

16. Canares $G$, Salgado T, Pines MS, Wolff MS. Effect of an $8.0 \%$ arginine and calcium carbonate desensitizing toothpaste on shear dentin bond strength. J Clin Dent 2012;23:68-70.

17. Marchan S, White D, Pruszynski J, Manwah T, Bassaw V, Smith W. The shear bond strengths of composite bonded to dentine following treatment with two dentine occluding desensitizing toothpastes. Open J Stomatol 2014:4:121-125.

18. Yang H, Pei D, Chen Z, Lei J, Zhou L, Huang C. Effects of the application sequence of calcium-containing desensitising pastes during etch-andrinse adhesive restoration. J Dent 2014;42:1115-1123.

19. Perdigao J. Dentin bonding-variables related to the clinical situation and the substrate treatment. Dent Mater 2010;26:e24-e37.

20. Addy M. Tooth brushing, tooth wear and dentine hypersensitivity-are they associated? Int Dent J 2005;55:261-267.

21. Macdonald $E$, North $A$, Maggio $B$, Sufi $F$, Mason $S$, Moore $C$, et al. Clinical study investigating abrasive effects of three toothpastes and water in an in situ model. J Dent 2010;38:509-516.
22. Diamanti I, Koletsi-Kounari H, Mamai-Homata E, Vougiouklakis G. Effect of fluoride and of calcium sodium phosphosilicate toothpastes on pre-softened dentin demineralization and remineralization in vitro. J Dent 2010;38:671-677.

23. Burwell AK, Litkowski $\sqcup$, Greenspan DC. Calcium sodium phosphosilicate (NovaMin): remineralization potential. Adv Dent Res 2009;21:35-39.

24. Wang Z, Jiang T, Sauro S, Pashley DH, Toledano M, Osorio R, et al.. The dentine remineralization activity of a desensitizing bioactive glasscontaining toothpaste: an in vitro study. Aust Dent J 2011;56:372-381.

25. Johannsen G, Tellefsen G, Johannsen A, Liljeborg A. The importance of measuring toothpaste abrasivity in both a quantitative and qualitative way. Acta Odontol Scand 2013;71:508-517.

26. Bruno M, Taddeo F, Medeiros IS, Boaro LC, Moreira MS, Marques MM, et al.. Relationship between toothpastes properties and patient-reported discomfort: crossover study. Clin Oral Investig 2015;20:485-494.

27. Liljeborg A, Tellefsen $G$, Johannsen $G$. The use of a profilometer for both quantitative and qualitative measurements of toothpaste abrasivity. Int J Dent Hygiene 2010;8:237-243.

28. Moore $\mathrm{C}$, Addy M. Wear of dentine in vitro by toothpaste abrasives and detergents alone and combined. J Clin Periodontol 2005;32:12421246. 